\title{
Fazer Viver e Deixar Morrer: a Velhice na Era do Biopoder
}

Make it Live and Let it Die: Old Age in Times of Biopower

Para Vivir y Dejar Morir: la Vejez en la Era del Biopoder
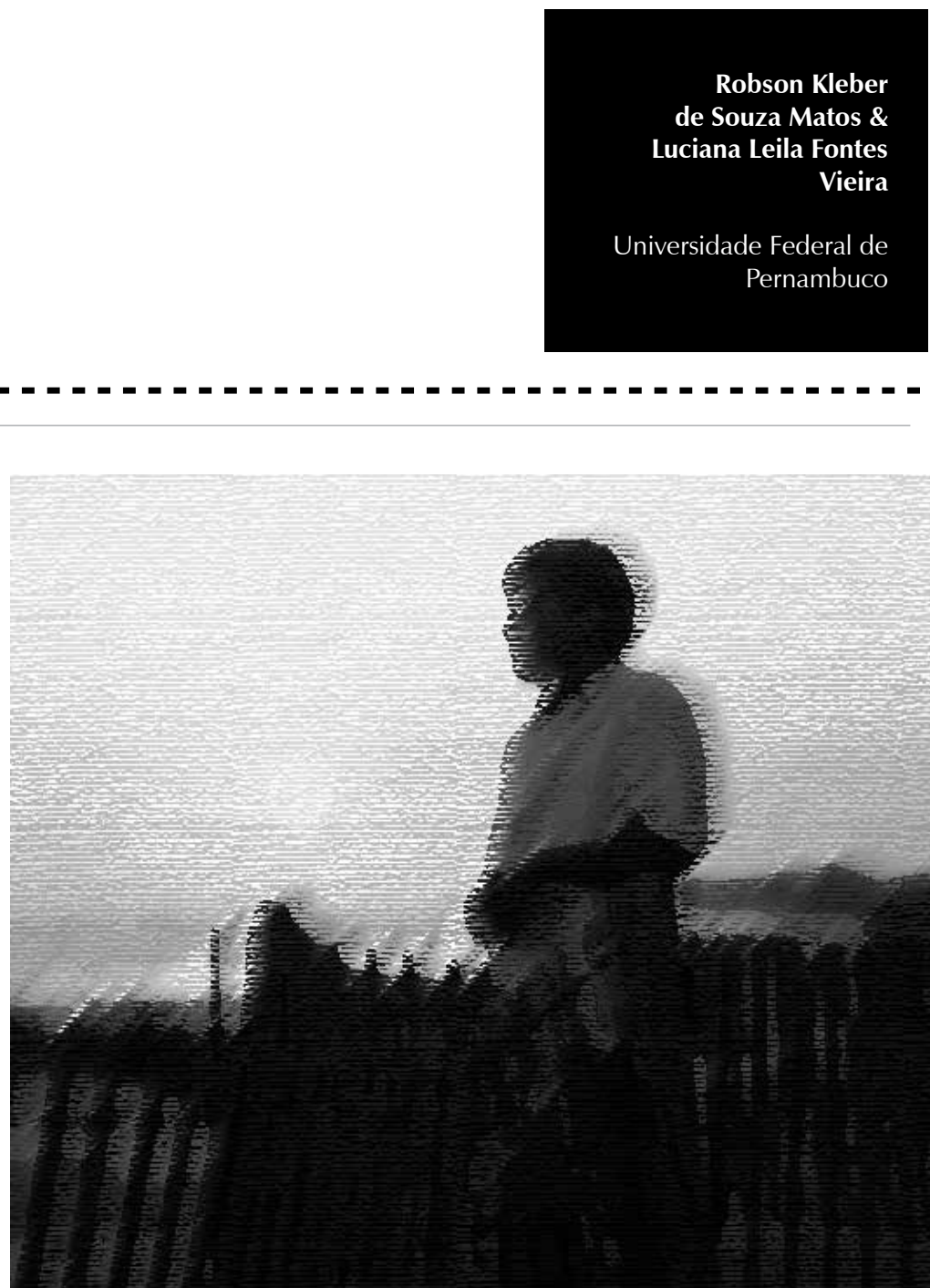
"Toda a gente desejaria viver muito tempo, mas ninguém quereria ser velho." (Swift, 1739)

Resumo: O presente artigo objetiva investigar a forma pela qual o biopoder incide sobre a construção da velhice na atualidade, principalmente, através do discurso médico-cientifico. Para tanto, a partir da obra foucaultiana, investigamos as origens, as características e as especificidades do poder disciplinar, da biopolítica e do biopoder, interrogando as suas incidências e as suas implicações em relação à posição de exclusão e de marginalização social do idoso. Espera-se, assim, repensar a posição do idoso e fomentar possibilidades para se construir uma nova imagem para essa parcela da população.

Palavras-chave: Idosos. Biopoder. Foucault, Michel, 1926-1984. Poder.

\begin{abstract}
This article aims to investigate the way in which biopower focuses on the social construction of old age nowadays, mostly represented by medical-scientific discourse. We discuss the implications of this power and its implication in the position of social exclusion and marginalization of the elderly in contemporary culture. We investigate the social construction of old age today and we seek to identify, from Foucault's work: 1) the origins, characteristics and specificities of biopower, and, 2) analyze the configurations of sovereign and disciplinary power. We hope thus to rethink the position of the elderly and foster opportunities for building a new image for this population.
\end{abstract}

Keywords: Aged. Biopower. Foucault, Michel, 1926-1984. Power.

Resumen: Este trabajo tiene como objetivo investigar la forma en que biopoder se centra en la construcción social de la vejez de hoy, representado en particular el discurso médico-científico. Discutimos las implicaciones de poder y su participación en la situación de exclusión social y la marginación de los anciones en la cultura contemporánea. Se investiga la construcción social de la vejez en hoy en día y tratar de identificar, a partir de la obra de Foucault, 1) orígenes, características y particularidades del biopoder, así como 2) revise la configuración del poder soberano y el poder disciplinario. Se espera, por lo tanto replantear la posición de las oportunidades y fomentar mayores para la construcción de una nueva imagen para esta porción de la población.

Palabras clave: Adultos mayores. Biopoder. Foucault, Michel, 1926-1984.Poder.

"Toda a gente desejaria viver muito tempo, mas ninguém quereria ser velho." (Swift,1739)

Datada de 1739 , no poema intitulado Versos sobre a Morte do Doutor Swift, a frase do poeta irlandês Jonathan Swift se mostra mais atual do que nunca. Ela retrata o conflito que comumente existe no sujeito contemporâneo: o de ter uma vida longa, pautada pela politização da vida, e o de envelhecer - processo no qual, muitas vezes, o indivíduo é logrado à condição existencial de perdedor devido à iminência da morte e da degeneração biológica que o acompanha.

Essa representação específica forjada ao longo da História - de que a velhice diminui as possibilidades do idoso de se inscrever de forma ativa na vida em sociedade e que vê esses sujeitos de uma forma estereotipada, substantivamente ligada à ideia de degeneração - hoje se configura como um problema social. Como indica Debert (1988), a transformação do envelhecimento em problema social retrata diversas dimensões: o desgaste fisiológico, o prolongamento da vida, o desequilíbrio demográfico e o custo financeiro das políticas sociais. Nesse contexto, a emergência de um número significativo de estudos que focam a velhice e o envelhecimento, as políticas públicas e diversas definições eufêmicas de velhice põe à vista um movimento que busca legitimar uma nova posição para os idosos na atualidade. É pontuando os fatores e as condições socio-históricas que contribuíram para a marginalização do idoso na sociedade moderna que se pode encontrar uma forma para se repensar sua condição. E, em um dos pontos cruciais que forjaram esse posto de exclusão, está a influência do biopoder - conceito apresentado por Foucault (1994) em 1976, em a História da Sexualidade I, a Vontade de Saber, no qual o autor apresenta a ideia de um poder que se situa e se exerce no nível da vida, da espécie, da raça e dos fenômenos maciços de população. 
Partindo dessa caracterização, investigouse aqui como o biopoder incide sobre a reordenação da velhice no imaginário social da cultura ocidental de hoje. Para tal, revisitamos o conceito abordado por Foucault ao longo de sua obra, a fim de dialogar e de pontuar as origens desse poder sobre a vida, o seu modo de configuração nos últimos três séculos e sua caracterização anátomo e biopolítica. Investigamos, também, a construção social da velhice ao longo das últimas quatro décadas, tendo como marco teórico inicial o ensaio A Velhice - obra seminal no estudo sobre o tema -, escrito por Simone de Beauvoir (1990) em 1970. Dessa forma, buscamos repensar a posição do idoso e fomentar possibilidades para se construir uma nova imagem para essa parcela da população.

\section{A velhice nas contingências do tempo}

"Todo mundo sabe: a condição das pessoas idosas é hoje escandalosa" (1990, p. 265). É com essa frase que Simone de Beauvoir inicia, nos anos 70, o seu robusto trabalho sobre a temática da velhice, no qual denunciava as precárias condições de vida dos idosos e a "conspiração de silêncio" e o descaso com que era tratada a velhice.

Desde então, durante as últimas cinco décadas, houve um nítido processo de envelhecimento da população mundial, o que fez a ONU (Organização das Nações Unidas) definir o período compreendido de 1975 a 2025 como A Era do Envelhecimento. Nesse cenário, o número de estudos e a repercussão dada aos temas ligados ao envelhecimento são debatidos em várias esferas da sociedade, onde o idoso passou a dividir o espaço com as outras faixas etárias, tanto em relação às políticas públicas quanto ao mercado.
Novos termos classificatórios são forjados com a finalidade de se desfazerem as tipificações negativas em relação à construção histórica em torno da velhice. Esses termos - boa idade, melhor idade, entre tantos outros buscam uma inversão na carga significativa dos seus precedentes, já que a prática linguística tem o poder de engendrar a subjetivação dos sujeitos, classificando-os e etiquetando-os, com o intuito de garantir direitos a um determinado grupo em função de outros, tangendo as normas estabelecidas no imaginário social (Costa, 1992). Sob essa perspectiva, a velhice muda de natureza: a ociosidade converte-se na prática de atividades sob o signo de dinamismo, de autogestão e de integração. A essas palavraschave, articulam-se uma nova definição e uma gama de equipamentos e de serviços que declaram a sociabilidade como seu Peixoto objetivo principal (Peixoto, 1998).

\footnotetext{
'A expressão 'terceira idade' não é um simples substituto do termo 'velhice'. O trabalho de classificação é indissociavelmente um trabalho de eufemização, e tem por objetivo tornar nomeável, ou seja, público, aquilo que até agora foi rechaçado e não pôde se exprimir (Lenoir, 1977 como citado em, 1998, p. 76)
}

Mesmo se constatando a transição demográfica e a maior visibilidade dos idosos, pode-se vislumbrar que a epígrafe de Beauvoir ainda encontra guarida em bases sólidas na atualidade. Apesar da maior sensibilidade aos problemas e da quebra do silêncio, vários aspectos da vida dos idosos têm sido negligenciados: a sexualidade (Silva et al., 2010), o corpo (Goldfarb, 1998) e a inserção ativa no mercado de trabalho (Wanjaman, Oliveira, \& Oliveira, 2004) são alguns exemplos.

Essas novas categorias esboçariam uma saída dessa condição escandalosa em que os 
idosos foram colocados, embora, por vezes, funcionem como máscara de uma realidade social que se mantém. A linha que separa essas duas posições é tênue. O movimento que busca legitimar uma nova posição social para o idoso - concentrado, sobretudo, na utilização de novos termos eufêmicos referentes à velhice - é, ainda, um rascunho fundamental, embora longe de ser resolutivo.

O fato de os idosos estarem em uma condição preocupante na atualidade não significa, necessariamente, considerar que em outros tempos tenha sido melhor. Não é o objetivo do nosso trabalho fazer uma cartografia da velhice, visto que as suas vicissitudes e particularidades, na História ocidental, são bastante vastas e bem trabalhadas em outros estudos (Beauvoir, 1990; Silva, 2008; Minois, 1999). Sendo assim, foi a partir de uma pequena passagem histórica que buscamos apresentar algumas perspectivas para avaliar a posição do idoso na era do biopoder.

Ao longo dos tempos, a ideia que se fez sobre a velhice mudou de acordo com interesses esconsos nas mais diversas sociedades, alternando períodos de valorização e de depreciação desse segmento social. O idoso, como categoria social e como será visto adiante, é um conceito relativamente novo. Até então, atrelava-se a essa coletividade a caracterização de um adulto em idade avançada. Esses sujeitos assumem a posição do outro, de um puro objeto, já que sua serventia para a sociedade não é mais a mesma - seja do ponto de vista da reprodução, seja do mercado de trabalho. Deles já não é mais esperada uma evolução (Beauvoir, 1990).

Dessa maneira, construiu-se, no decorrer da História ocidental - sobretudo da Idade Média ao Renascimento - a ideia de velhice como o inverso da vida. Em relação à juventude e à maturidade, ela é vista como uma espécie de referência negativa. Apenas como ilustração, pontuarei aqui alguns eventos que foram relevantes nos contornos negativos direcionados aos idosos (Minois, 1999).

O primeiro foi a queda do Império Romano e a consequente ascensão do Cristianismo, que se impôs no seio do império romano e dos bárbaros e passou a ser degradado pelos costumes dos povos que dominou. Seu ideal primitivo de fraternidade e de solidariedade, por exemplo, perde força no espaço social, regido bem mais pelo acaso das armas do que por instituições estáveis. Os jovens passaram a conduzir o mundo, e os velhos se viram excluídos da vida pública. Assim, a religião não pôde melhorar os destinos dos velhos, apesar da construção de asilos e de hospitais no século IV que se destinavam ao atendimento dos órfãos e dos doentes. Nessa perspectiva, mesmo que em algum momento os velhos tenham se beneficiado dessas iniciativas, em termos gerais, o Cristianismo expôs uma visão negativa da velhice. Esse aspecto fica claro ao se analisar obras de escritores cristãos - Santo Agostinho, por exemplo - que mencionavam a velhice com relação à moral, associando-a à decrepitude, à feiúra e ao pecado (Minois, 1999).

O segundo evento ocorreu por volta do século VIII, com o sistema feudal. Apesar de a vassalagem não ser relegada com o tempo, os vassalos precisavam a todo instante defender os feudos com armas. Quando o avançar da idade chega ao ponto de tornar o vassalo incapaz de pegar em armas e lutar, ele passa a ser colocado à parte. No entanto, a força física não era requerida apenas na vassalagem: entre os nobres, há o treinamento dado ao jovem para que se torne um cavaleiro. Analisando a literatura da época, é visível a indiferença em relação aos idosos e ao envelhecimento, e, quando heróis velhos são citados, eles são retratados como se estivessem no auge e na força da idade, como mostra Beavouir (1990): Lancelote, Guinevere e Gauvain - 
Em Romeu

e Julieta,

ele faz uma descrição sem complacência do velho,

ao dizer que

"muitos velhos já parecem estar mortos; são pálidos, lentos, pesados e inertes como chumbo" (Beauvoir, 1990). no romance Na Morte de Arthur, escrito em 1495 - tinham entre 60 e 80 anos, e comportavam-se como homens no esplendor da juventude. Com os jovens que continuam a conduzir o mundo, a situação dos velhos é extremamente desfavorecida em todos os setores da sociedade. É a partir disso, então, que acontece a identificação da velhice com o término das atividades, silenciando os velhos, ignorando-os e iniciando a concepção moderna da reclusão em retiros (Beauvoir, 1990; Silva, 2008).

O terceiro evento relevante se dá a partir do século XIV, no contexto da Renascença, que é quando se passa a exaltar a beleza e a juventude, sobretudo a do corpo. Dessa forma, a velhice passa a ser tratada como detestável, um estágio de vida em que todas as riquezas da juventude foram tiradas.

Em resumo, os velhos são portadores de tudo aquilo que não é desejado. O idoso não apenas é ignorado, mas atacado. Nesse contexto, vários autores personificaram diversos aspectos da velhice, dentre os quais William Shakespeare se sobressai. Em Romeu e Julieta, ele faz uma descrição sem complacência do velho, ao dizer que "muitos velhos já parecem estar mortos; são pálidos, lentos, pesados e inertes como chumbo" (Beauvoir, 1990).

Essa posição frente aos idosos pode ser entendida analisando as condições em que a Europa vivia nos séculos XIV e XV. Nessa época, houve um ressurgimento da vida nas cidades, com expansão do comércio e do mercantilismo. Surge, assim, um capitalismo embrionário, e, com ele, uma nova classe que conseguiu uma ascensão individual: a burguesia. Na ocasião, não se fala dos velhos nobres e patrícios - pois admite-se que esses possuam poder e fortuna por direito divino - nem daqueles de classes inferiores, mas, sobretudo, dos velhos novos-ricos. Beauvoir exemplifica bem essa situação:
Se os negócios prosperam, ele é detentor, nos últimos anos de vida, de bens consideráveis: aos olhos do homem maduro que trabalha para sobreviver, aos olhos da juventude freqüentemente sem dinheiro, esse monopólio aparece com uma injustiça, provoca uma inveja rancorosa, atribui-se esse sucesso à avareza. (...) As pessoas vingam-se dos velhos, tentam provocar-lhes repugnância por seus 'vícios', caricaturando-os cruelmente, ou rindo de suas caricaturas: contra eles, autores e o público são cúmplices (1990, pp. 191, 192)

Em meados do século XVII, a relação e o manejo do idoso ganham um novo cenário: novas técnicas foram criadas, a ciência, a fisiologia, a anatomia e diversas outras áreas se desenvolveram, e o idoso passou a ser estudado, examinado, comentado. Os mitos em torno da velhice são, sistematicamente, sucedidos pelo conhecimento socialmente legitimado. É a partir desse ponto que a influência do biopoder incidirá preponderantemente sobre a representação que se faz da velhice na cultura ocidental.

\section{Do poder soberano ao biopoder}

Antes de nos debruçamos sobre os escritos referentes ao biopoder, cumpre ressaltar, brevemente, as múltiplas facetas do poder na obra foucaultiana. Costuma-se dividir a obra de Foucault em dois momentos: um primeiro, referente à fase genealógica, no qual o autor concentra seu estudo na questão do poder-saber, em que o sujeito aparece como um simples efeito das relações de poder, e um segundo momento, no final da sua vida, quando o autor passa a preocupar-se com a hermenêutica do sujeito, articulando as noções do cuidado consigo mesmo e com a estética da existência, que é quando as formas de subjetivação são tecidas em um complexo processo que envolve as relações de saber, de poder e do sujeito consigo mesmo. 
É importante lembrar que Foucault nunca construiu uma teoria geral e universalista sobre poder. No máximo, indicou algumas precauções metodológicas, já que seu interesse se destinava a compreender o como do poder, o modo como ele se coloca entre o Direito - as regras pelas quais o poder é formalmente limitado - e a verdade, ou ao menos os efeitos de verdade produzidos, transmitidos e reproduzidos por esse poder. Em suma, a relação entre três fatores que se influenciam mutuamente: poder, Direito e verdade (Foucault, 1993).

Nas sociedades ocidentais, desde a Idade Média, essas relações supracitadas entre Direito e poder serviram de base para construção do pensamento jurídico, que girava essencialmente em torno do poder real, do poder soberano. Foucault buscou inverter a direção dessa análise do discurso do Direito. Uma frase que ecoa paradigmática, no que tange a essa questão, foi escrita por ele no primeiro volume da História da Sexualidade, no qual afirma que busca "construir um desejo sem lei e um poder sem rei" (1994, p. 87): uma concepção completamente nova de poder, que rompe qualquer ideia de poder préexistente. Pensar em um poder sem rei é pensar sobre o poder sem que ele seja reservado a uma fonte que o detenha, que determine sua natureza, seus limites e seu modo de funcionamento. Nesse sentido, em vez de derivar de uma superioridade, de ser exercido intermitentemente e de agir de cima para baixo, o poder seria concebido a partir de um conjunto de relações, do seu exercício permanente e de uma irradiação de baixo para cima, sustentando as instâncias de autoridade. Em lugar de apenas esmagar e confiscar, o poder incentiva e faz produzir (Albuquerque, 1995).

Falar de um poder com rei, representado na figura do soberano, fica mais inteligível a partir do paradoxo teórico do direito clássico da soberania de "deixar viver e fazer morrer", apresentado por Foucault no livro Em Defesa da Sociedade:

Em certo sentido, dizer que o soberano tem direito à vida e à morte significa, no fundo, que ele pode fazer morrer e deixar viver; (...) Em relação ao poder, o súdito não é, de pleno direito, nem vivo e nem morto. Ele é, do ponto de vista da vida e da morte, neutro, é simplesmente por causa do soberano que o súdito tem o direito de estar vivo ou tem direito, eventualmente, de estar morto (1999, p. 286)

Através desse direito básico do soberano, podem-se inferir algumas características pelas quais os mecanismos, as técnicas e as tecnologias de poder soberano se exerciam/ se exercem. Na tentativa de delimitar um tempo histórico, ainda que vago, esse poder produziu-se antes do século XVII. Diretamente atrelado à figura de um soberano ou, contemporaneamente, na visão de Estado como ser coletivo, esse poder carrega uma conotação negativa associada à lei jurídica, à repressão e à interdição. No conceito da soberania, imagina-se uma forma de poder que se exerce muito mais sobre a terra e seus produtos, fiscalizado continuamente através de um sistema de taxas e de obrigações (Foucault, 1993).

Com o desenvolvimento econômico, a explosão demográfica e a industrialização, o poder soberano acabou tornandose inoperante. É somente em meados do século XVI e início do século XVII - concomitantemente à ascensão da burguesia - que o Ocidente vai conhecer uma transformação muito profunda nesse mecanismo de poder. Começam a surgir técnicas que não se centravam mais no indivíduo-sociedade, na lei ou na existência física de um soberano, mas nas técnicas de poder, que tinham como foco o indívíduocorpo, a disciplina e a normalização de costumes. Esse novo mecanismo de poder, 
chamado por Foucault de poder disciplinar, passa a apoiar-se no corpo e nos seus atos, não mais na terra e nos seus produtos. Dessa maneira,

não se fala exatamente em substituir, mas em completar esse velho direito de soberania - fazer morrer e deixar viver com outro direito novo, que não vai apagar o primeiro, mas vai penetrá-lo, perpassálo, modificá-lo, e que vai ser um direito, ou melhor, um poder exatamente inverso: o poder de 'fazer' viver e de 'deixar' morrer (1999, p. 287)

Com isso, o direito de morte que outrora era concebido ao arbítrio e à necessidade do soberano, agora vai apoiar-se nas exigências de um corpo social a fim de garantir vida, mantê-la e desenvolvê-la.

Há uma penetração do poder na vida, uma tomada de poder do homem como ser vivo, uma espécie de estatização do biológico. Foi então, a partir dos séculos XVII e XVIII, que novas tecnologias de poder - centradas no corpo individual, na vida e nos seus fenômenos - se constituíram associadas à ascensão da burguesia no corpo social europeu. Era preciso aumentar as potencialidades desses corpos, sobretudo como força produtiva, além de lançar mão de procedimentos pelos quais se assegurava a distribuição espacial dos corpos individuais - seu alinhamento, sua separação, sua colocação em série e em vigilância constante (Foucault, 1999). Sobre o papel da burguesia nesse processo, Foucault explica:

Deve-se suspeitar, nesse caso, de autoafirmação de uma classe e não de sujeição a outra: uma defesa, uma proteção, um reforço, uma exaltação que mais tarde foram estendidos - à custa de diferentes transformações - a outros meios de controle econômico e sujeição política. Nesse investimento sobre o próprio sexo, por meio de uma tecnologia de poder e de saber inventadas por ela própria, a burguesia fazia valer o alto preço político de seu próprio corpo, de suas sensações, seus prazeres, sua saúde, sua sobrevivência. É um agente político da vida, que se constituiu não através da submissão de outrem, mas numa afirmação de si (1994, p.116)

Esse cenário vai promover importantes reverberações para construção da subjetividade na modernidade, no final do século XVIII e no início do XIX. É por meio dessa disciplina de corpos - ao mesmo tempo normatizadora e individualizante - que se busca a produção de vida. O poder soberano de tirar a vida dá lugar ao poder de fazer vida, e, por trás das cortinas sociais, o deixar morrer para os corpos que já não têm utilidade, que não mais se encaixam.

Toda essa nova tecnologia é assegurada por meio do poder disciplinar, da disciplina que se exerce continuamente em forma de treinamento e de vigilância global e individualizante, mediados por instituições como escola, hospital, quartel. Como consequência do controle disciplinar, podemos observar a emergência do cientificismo e a consequente construção de uma anátomopolítica do corpo humano.

O saber científico, aliado ao saber médico, serão os instrumentos sobre o quais biopoder se sustentará, legitimando verdades na cultura moderna, regulamentando, disciplinarizando e criando corpos marginais. Para entender esse processo, é preciso adentrar pelo conceito de biopolítica, que é complementar a essa tecnologia disciplinar e que é onde se configura o poder sobre a vida.

A partir da metade do século XVIII, além da disciplina dos corpos, era necessário cuidar da população como um todo. O foco passa, portanto, do indivíduo/corpo da anátomopolítica e do indivíduo/sociedade do poder soberano para o indivíduo como espécie. A biopolítica vai focar a vida e os fenômenos a ela relacionados: natalidade, morbidade, 
A biopolítica designa as condições de possibilidade de uma prática de liberdade ancorada na potência da vida (Foucault, 1999). incapacidades biológicas diversas, efeitos do meio. Nas palavras de Foucault:

Não é com a sociedade que lida essa nova tecnologia de poder; não é tampouco com o indivíduo corpo. É um novo corpo: o corpo múltiplo, corpo com inúmeras cabeças, se não infinito pelo menos necessariamente numerável. É a noção de 'população'. A biopolítica lida com a população, e a população como problema político, como problema ao mesmo tempo científico e político, como problema biológico, e como problema de poder, acho que aparece nesse momento (1999, p, 293)

Em suma, o termo biopolítica refere-se ao modo como o poder se transformou, entre o final do século XVIII e o início do século XIX, a fim de governar não somente os indivíduos através de procedimentos disciplinares (anátomo-política) mas também o conjunto da população. A biopolítica, por meio dos biopoderes locais, ocupar-se-á da gestão da saúde, higiene, alimentação, sexualidade e natalidade na medida em que estes se tornaram capital político. A biopolítica designa as condições de possibilidade de uma prática de liberdade ancorada na potência da vida (Foucault, 1999).

Para aprofundarmos o entendimento das estratégias da biopolítica, na atualidade, faz-se necessária a análise das noções de governamento e de governamentalidade. Segundo Veiga-Neto \& Lopes (2007), governamento designa todo conjunto de ações que objetivam conduzir deliberadamente a própria conduta ou a conduta dos outros. Nas palavras de Foucault, "visam estruturar o eventual campo de ação dos outros" (2008, p.244). Essa noção, portanto, ultrapassa o âmbito do governo, representado tão somente pelas instâncias do Estado, pois designa o "conjunto de ações - dispersas, disseminadas e microfísicas de poder - que objetivam conduzir ou estruturar a população" (2010, p. 952), podendo ser ou não exercida pelo
Estado. Dito de outra forma, Castro observa que a governamentalidade é "o conjunto constituído pelas instituições, procedimentos, análises e reflexões, cálculos e táticas que permitem exercer essa forma de poder que tem, por objetivo principal, a população" (2009, p.120).

Dessa forma, a biopolítica, por meio da governamentalidade, visa a implantar novas tecnologias interessadas em agrupar e em modificar os efeitos de massa, próprios da população, em assegurar uma disciplina e uma regulamentação da vida e dos processos biológicos. Esses interesses são diferentes, embora complementares, dos mecanismos da anátomo-política. Inicia-se, assim, a era do biopoder, obcecado pelo cuidado purificador da vida e dotado de uma gestão calculista da vida no corpo social. Mais do que nunca, é focada a busca em uma eugenia da população - em que aqueles que não se adaptam representam uma ameaça à espécie - e ganha força o enunciado do fazer viver e deixar morrer.

Se o cientificismo é, ao mesmo tempo, causa e consequência do desenvolvimento de saberes específicos sobre o corpo, a Medicina - e, mais especificamente, o processo de medicalização ocorrido no Ocidente no século XVIII - tem importância estratégica no desenvolvimento da biopolítica. Como mostra Birman (2006), o processo de medicalização do Ocidente representa uma dessacralização da cultura ocidental, quando a cura passa a ocupar o lugar que antes era da salvação. Assim, a regulação política do espaço social se deu por meio do discurso da Medicina, que se fez intervencionista, articulando os registros de saber e poder com o intuito de promover a gestão efetiva dos viventes no espaço social. A saúde de uma população como objetivo geral e urgência de todos faz com que a Medicina saia, portanto, de um nicho específico - direcionada especificamente aos pobres - para se aplicar à sociedade como um todo (Foucault, 1998). 
Algumas condições sustentaram o desenvolvimento do poder sobre a vida, como, por exemplo, a preservação, a manutenção e a conservação da força de trabalho. Com o grande crescimento demográfico do século XVIII, criou-se a necessidade de se controlar e de integrar os aparelhos de produção, fazendo surgir a população - com todas as suas variáveis possíveis, desde sua repartição espacial até suas condições de saúde. Dessa maneira, os traços biológicos de uma população passam a ser elementos fundamentais para uma gestão econômica. Foi tentando organizarse em torno desses traços que se configurou o poder sobre a vida, que buscava um aumento constante da utilidade dos corpos (Foucault, 1993).

Apenas a partir dos séculos XVIII e XIX o sujeito passa a fundar-se em ciclos biológicos bem definidos, que é quando se institui a construção social da velhice (Birman, 1997). Em uma sociedade que vê o corpo como máquina, - e que prioriza sua força produtiva econômica e baseada na eugenia - valores e tipificações negativas são atribuídas à velhice. Investigar a influência do biopoder na construção social da velhice é o próximo tópico deste trabalho.

\section{Velhice e biopoder}

Pudemos perceber a transição de uma cultura - quando o corpo não possuía uma função específica - para uma outra, representada por uma extrema racionalização que busca extrair o máximo do seu potencial da vida. Através de um saber biomédico, que agora se faz intervencionista e busca promover uma gestão efetiva dos viventes no espaço social, cria-se um modelo de corpo que vai subjugar e afastar assepticamente do âmbito social qualquer corpo que se distancie dele. É inegável que o corpo velho seja marcado por um fenômeno biológico que apresente certas singularidades, mas o que se impõe como questão é: de que maneira os jogos de poder perpassam, caracterizam e constituem esse corpo na nossa sociedade? Vale salientar que o corpo, na perspectiva foucaultiana, não se limita às concepções orgânicas, pois concerne a um campo onde operam diferentes dispositivos.

Nesse sentido, a descoberta da velhice seria marcada pelo corpo envelhecido, não sendo o velho singularizado no que tange ao seu comportamento e às suas condições sociais, mas estabelecido em relação a uma norma. Assim, seu corpo é visto como sombra daquele corpo que outrora foi jovem, útil e bonito, e que agora não passa de um corpo impotente que necessita de cuidados. As insígnias atreladas à velhice denotam a promessa daquilo que falta e o flerte com o patológico.

Dessa forma, através da Medicina clínica e social, a normalização como hábito e exercício cria saberes e verdades que não apenas justificam, mas apontam se o indivíduo se conduz ou não sob formas instituídas. Porém, para tentar circunscrever o modo como a normalização age sobre a população idosa, é preciso desenovelar seus modos de ação bem como explicar os porquês dessa exclusão de determinados corpos na sociedade moderna (Foucault, 2008).

Antes de tudo, é preciso pontuar a disciplinarização como função corretiva que tem por finalidade reduzir os desvios e os mecanismos regulamentadores, característicos do biopoder, e que integram e potencializam o caráter normativo da disciplina. A disciplinarização atua catalogando os indivíduos, separando-os de acordo com suas potencialidades e seus níveis de valor: analisa, decompõe indivíduos, lugares, tempo, gestos, tanto no sentido de percebê-los quanto de modificá-los. Em seguida, ocorre uma ordenação desses elementos, classificados em torno de objetivos determinados - por exemplo, quais são os operários mais aptos 


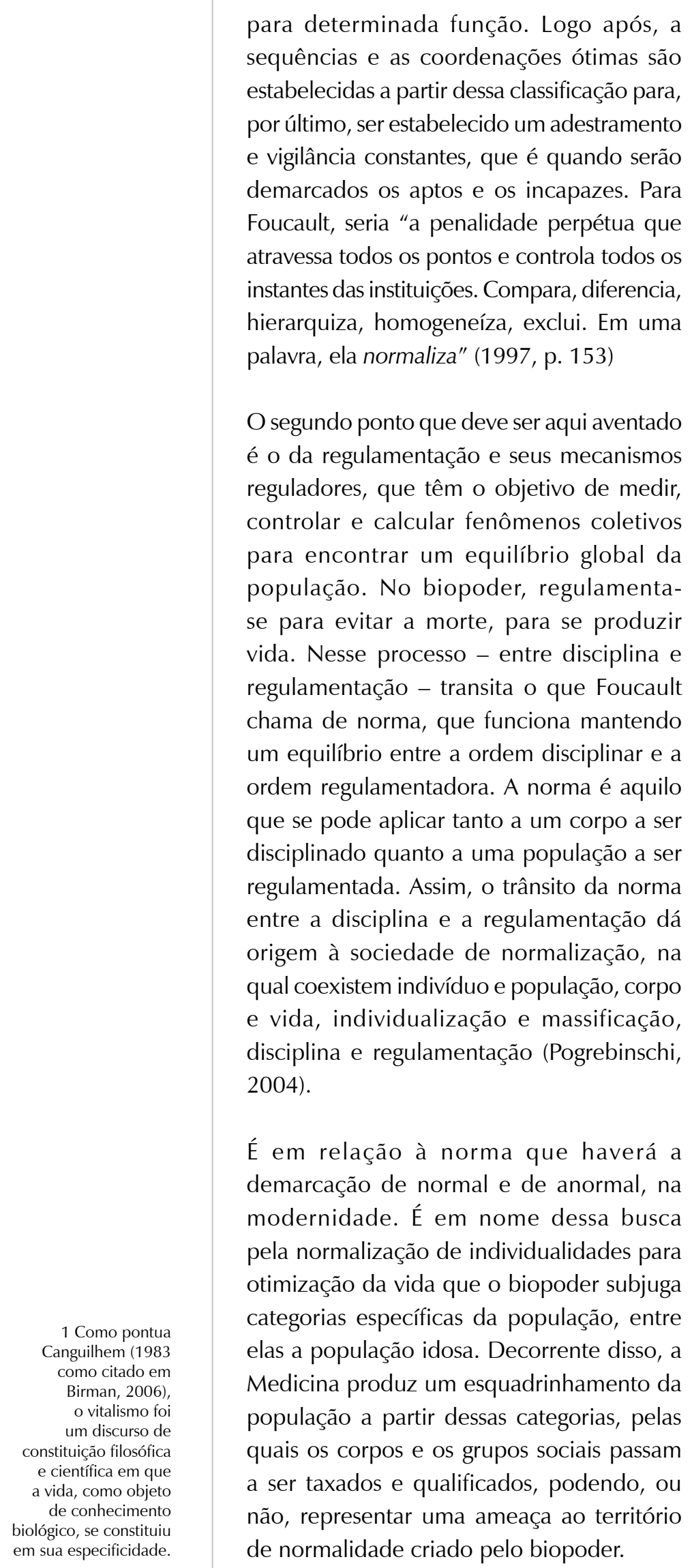

\section{Envelhecer - imperativo do novo}

Como mostra Foucault (1998), a partir dos séculos XVIII e XIX, muda-se o trato que a Medicina tem com a doença: desloca-se o seu modo de explicação, o qual busca as origens da doença na superfície do corpo, em vez de se associá-la a divindades e ao cosmos. A partir disso, o corpo envelhecido é delineado de forma a serem reconhecidas diferenças em relação ao corpo jovem. Não por acaso, já no início do século XX, cria-se a geriatria como especialização médica, destinada a regulamentar um novo discurso sobre o envelhecer, que se baseava, sobretudo, nos estudos pré-geriátricos de Charcot e Bichat, e que serviu de base para as modernas práticas sobre a velhice e o envelhecimento (Groisman, 2002). Esses estudos propunham, através de uma série de técnicas e de teorias, uma nova forma de enxergar a velhice, sem considerá-la um puro vitalismo ${ }^{1}$, mas levando em conta suas condições anatômicas e fisiológicas singulares. (Haber, 1986 como citado em Groisman, 2002)

A maior contribuição de Bichat foi uma anatomia baseada em uma teoria de tecidos: a doença teoria origem nos tecidos e depois comprometeria os órgãos. Isso significaria que a vida em tecidos seria a própria vida em miniatura, a doença e a morte não seriam processos exteriores ao corpo, mas sim, intrínsecos a ele (Katz, 1996). Nessa perspectiva, o envelhecimento estaria diretamente ligado à morte, uma vez que haveria deterioração dos tecidos na velhice. O que Bichat e seus seguidores fizeram, com seu vitalismo moderno, foi organizar uma nova percepção do corpo, que, desta vez, não trata a velhice como enfraquecimento ou declínio, mas como um corpo que está morrendo. Organiza-se, então, um conhecimento em torno de algo que precisa 
"(...) nesta nova imagem que dá de si mesma, a experiência clínica se arma para explorar um novo espaço: o espaço tangível do corpo, que é ao mesmo tempo essa massa opaca que oculta segredos, invisíveis lesões e o próprio mistério das origens" (Foucault, 1998, p. 139). ser tratado, subvertido. Os estudos de Bichat representam uma virada no saber clínico: “(...) nesta nova imagem que dá de si mesma, a experiência clínica se arma para explorar um novo espaço: o espaço tangível do corpo, que é ao mesmo tempo essa massa opaca que oculta segredos, invisíveis lesões e o próprio mistério das origens" (Foucault, 1998, p. 139).

Não é exagero dizer que Bichat relativizou o conceito de morte, descentrando a ideia de ser esse um acontecimento indivisível, decisivo e irrecuperável. O que fez com suas teorias foi relativizar e repartir a vida, em formas de morte a varejo, parciais, progressivas e de conclusão lenta (Foucault, 1998).

Delineia-se, assim, uma das derrocadas mais marcantes da velhice na contemporaneidade: sua associação à morte e seu iminente declínio biológico, agora visto e tratado como doença, interligando a velhice ao patológico. O envelhecimento se transforma em enfermidade, e a morte deve ser exorcizada do meio social, já que tem reverberações cruciais na população que é vista mais próxima dela. O poder que outrora tinha como ponto central o direito de fazer morrer, agora intervém para fazer viver. Nesse contexto, onde a mortalidade se torna o outro do poder, envelhecer e morrer representam o fracasso de uma cultura em que o novo e a atividade são seus maiores expoentes.

A partir disso, o projeto contemporâneo de viver bem prega a adoção de determinados atos e hábitos que têm no jovem e na jovialidade seus representantes máximos. Logo, cabe ao velho o esforço em seguilos, caso não queiram ser vistos como inadequados e impróprios. Pesquisas como as de Soares (2005) - em que se denuncia a crise de identidade que os idosos sofrem ao chegar à velhice - ou mesmo os trabalhos de Pitanga (2006) e de Goldfarb (1998), com uma leitura mais psicanalítica que apontam a desnarcização do sujeito velho, refletem o mal-estar gerado no sujeito que envelhece devido a esse progressivo ofuscamento de seus sentidos de existência e dessa ânsia por permanecer jovem da cultura moderna. O emparelhamento com a morte, com a finitude da vida, com a improdutividade, faz com que esses sujeitos tenham sintomas de morte muito antes da morte em si. Muitas vezes tratada de forma cômica, a crise de meia-idade pode representar esse início de desvalorização: não querer parecer velho para não ser desvalorizado socialmente.

Em seu ensaio intitulado A Solidão dos Moribundos - sobre Envelhecer e Morrer, Elias (2001) faz uma narrativa sobre a morte e o envelhecimento na qual relaciona sua experiência pessoal com o saber médico. Trata-se de um discurso sobre a velhice feito por um velho, direcionado aos médicos. $\mathrm{O}$ autor sustenta que, na sociedade moderna, a velhice e a morte foram sendo paulatinamente colocadas na esfera privada, ficando à mercê de especialistas. Assim, ao velho não cabe mais depender de si mesmo, mas buscar ajuda especializada para viver e morrer. Cabe a ele, nesse ponto, apenas a culpa pela própria decadência, o que pacifica a sensibilidade dos mais jovens. Essa carência de identidade e simpatia acaba gerando isolamento e solidão naqueles que envelhecem, e revelam o que é se sentir excluído do meio ainda vivente (2001 como citado em Agra Do Ó, 2008).

Nesse ponto, a morte passa a ser não mais aquela que se abate sobre a vida de forma abrupta, mas que penetra a vida de forma sorrateira, percorrendo-a paulatinamente, diminuindo-a, enfraquecendo-a. A vida vale tanto menos quanto mais próxima estiver da morte. O idoso é impossibilitado de participar de forma ativa da vida em sociedade e está jogado em um arcabouço de preconceitos, no qual é oferecida como saída ou a imitação do jovem ou o isolamento. 
Além do aspecto destacado em relação à aproximação entre morte e velhice, é preciso evocar outro aspecto correlato que reflete a relação entre Medicina e velhice e que contribui significativamente para o isolamento do idoso na cultura moderna, que é a associação da velhice à patologia.

\section{Da normalidade à patologia}

A aproximação entre velhice e patologia encontra seu cerne - além das experiências supracitadas de Bichat - nas pesquisas de Charcot, baseadas em seus anos de estudo em Salpetrière, o maior hospital da Europa, que abrigava cerca de oito mil doentes, dentre os quais cerca de dois mil idosos. Não é exagero dizer que Salpetrière foi uma espécie de primeira instituição geriátrica do mundo. Nesse contexto, Charcot fez pesquisas que tinham por objetivo estudar o processo de envelhecimento, suas causas e consequências sobre o organismo. Ele considerava que a velhice devia ser considerada separadamente, e que as mudanças na textura dos tecidos/órgãos às vezes atingiam um ponto que impossibilitava discernir os aspectos fisiológicos e patológicos do corpo, traçar a linha precisa entre doença e saúde. A partir desses estudos, pôde-se perceber que a Medicina preventiva foi cedendo lugar à terapêutica, que tinha a preocupação de curar o idoso (Beauvoir, 1990; Groisman, 2002).

Beauvoir cita os gregos, como Hipócrates, que consideravam a doença e a velhice resultantes de um desequilíbrio entre sangue, fleuma, bile amarela e bile negra.

2 Publicação que aborda assuntos ligados à ciência, história, tecnologia, religião e saúde, e que tem como objetivo trazer ao leitor o que o campo de conhecimento humano pode trazer no futuro. Seu slogan o futuro antes indica isso.
Em seguida, veio a geriatria, criada pelo médico norte-americano Leo Nasher, em 1909, que se concentrava na área médica e biomédica e que tinha como objetivo criar uma especialidade para o trato dos idosos, seguindo os moldes da pediatria (Katz, 1996). O que se percebe nessa descoberta da velhice pela Medicina é que, talvez pela primeira vez, os velhos foram vistos como uma entidade demográfica específica, uma população que demanda cuidados especiais. Em contrapartida, desde os primórdios, as intervenções são centradas no corpo envelhecido, ficando em segundo plano a singularidade do velho em relação ao seu comportamento e às suas condições sociais.

A revista Galile ${ }^{2}$ traz em sua capa a manchete A Cura Para o Envelhecimento, em que apresenta ao leitor "as novas armas da ciência para evitar doenças, regenerar órgãos e nos manter com aparência jovem para sempre" (2011, p.1). Essa revista é bem sintomática no que se refere à abordagem atual da nova ciência em relação ao envelhecimento, a ciência do antienvelhecimento. Já não se busca mais atacar doenças específicas, mas o envelhecimento como um todo e todas as formas de deterioração do corpo. Busca-se agora, em um tom matuzaleico, um prolongamento da vida, uma juventude eterna: "atacar a velhice, portanto, seria a melhor e talvez a única forma de nos afastarmos dos males provocados por ela" (2011, p. 37), diz a revista. Os meios para se conseguir isso são diversos: pílulas, dietas, injeções antienvelhecimento, tratamentos com células-tronco, medicina regenerativa e até bioengenharia. Não cabe, aqui, determo-nos no modo de funcionamento e nas particularidades de cada tratamento, tampouco utilizarmos a crítica naturalista em prol de não ferir a ordem natural da vida - a ideia de algo natural é quase tão perigosa quanto a de antinatural. Também não é cabível uma demonização da Medicina: se há um número crescente de idosos 


\section{Como pontua \\ Canguilhem \\ (2002), a nossa sociedade torna-se algo a ser contornado, consertado, retraído: o velho precisa agir contra a velhice, ser tratado.}

tende a achar

que jovialidade é sinônimo de saúde, construindo, dessa maneira, uma correlação entre doença $e$ velhice.

Como pontua Canguilhem (2002), a nossa sociedade tende a achar que jovialidade é sinônimo de saúde, construindo, dessa maneira, uma correlação entre doença e velhice. A velhice é considerada em relação a uma norma e, em relação a ela, representa atualmente, deve-se creditar isso, também, à medicalização da vida, às evoluções da Medicina e da biologia, que é o que Foucault caracterizaria como a positividade do poder.

O que acontece é que, sob uma pretensa alegação de melhoria da qualidade de vida da população e de melhores condições sociais, substituem-se gradualmente hierarquizações sociais anteriores por uma cultura delineada pelo biopoder, em que o risco da morte e o pânico se concentram no corpo, em uma dinâmica de poder concentrada na norma. Essa criação de uma nova hierarquização de subjetividades leva em conta o potencial dos corpos: a hierarquização biológica dos seres. Ter saúde seria seguir normas. A velhice uma carência. O que se desconsidera nesse contexto é que a velhice não se limita a um conceito: ela configura-se como uma experiência composta de uma complexidade de fatores. Ser velho na Suécia é diferente de ser velho no Brasil, da mesma maneira que ser velho no Nordeste brasileiro é diferente de ser velho no Sudeste. Envelhecer engendra uma série de múltiplos significados e construções, que precisam ser levados em conta na sua aproximação com a patologia e com a ideia que se tem de normalidade.

Canguilhem, em O Normal e o Patológico (2002), oferece uma alternativa para se repensar essa posição frente ao binômio normal/patológico na cultura moderna. $\mathrm{Na}$ perspectiva vigente - de base médicocientífica -, o que diferencia patologia e normalidade é dado por variações quantitativas dos fenômenos normais, sendo o estado patológico aquele que excede ou falta no que diz respeito a determinados estímulos relacionados ao estado de saúde/ normal. Para Canguilhem, saúde implica desobedecer, transformar-se, entrar e sair do estado patológico. A patologia representaria a fixidez, a impossibilidade de mudança e a rigidez em relação à norma. O que está em pauta na sua tese é que "as reações patológicas jamais se apresentam no indivíduo normal da mesma forma e das mesmas condições, pois o patológico implica uma relação com um meio novo, mais limitado, já que o doente não consegue mais responder às exigências do meio normal anterior" (Coelho \& Almeida Filho, 1999, p. 17).

A partir de Canguilhem, a doença devia ser considerada de maneira qualitativa, sendo a norma vital variável com o meio e com o uso que o sujeito faz desse meio. Ela não seria resultado de um exame bacteriológico ou histológico, por exemplo: eles não serviriam como diagnóstico de uma doença. É preciso considerar o comportamento do doente. Existiriam diferentes normalidades, e a norma seria sempre individual, estabelecida de forma relacional, em relação à capacidade de se adaptar do sujeito. A normalidade, então, não seria definida a partir de certa média; eventuais desvios individuais não seriam considerados patológicos: existiriam diferentes normalidades, nas quais cada indivíduo definiria o normal para ele mesmo (Canguilhem, 2006; Coelho \& Almeida Filho, 1999).

Nessa visão, o velho saudável não seria uma "ficção de poeta", como diz Canguilhem (2006, p.80). A velhice seria considerada não patológica a partir do momento em que os sujeitos mostrassem uma capacidade de adaptação ou de reparação dos desgastes orgânicos a que fossem submetidos. Como explicam Deleuze \& Guatari, "envelhecer não 
é permanecer jovem, é extrair da sua idade as particularidades, as velocidades e lentidões, os fluxos que constituem a juventude dessa idade" (1997, p. 70). Essa seria uma saída para se repensar a relação de velhice e doença na contemporaneidade: observar a singularidade de cada idoso, separada de todo apresto criado pela biopolítica, que está mais preocupada em geri-los do que, de fato, em cuidá-los.

\section{O novo velho}

É sob esse fundo difuso que, atualmente sobretudo nos países em desenvolvimento como o Brasil -, se pode perceber uma reordenação da velhice, na qual o envelhecimento demográfico, o potencial mercado consumidor e alguns outros fatores econômicos são colocados no meio social como problemas que necessitam de urgentes soluções. Não por acaso, quando se pensa em velhice, logo vêm à mente aposentadoria, doença, previdência social, impostos. Apesar de problemas como seguridade social e saúde pública estarem no cerne dessa reestruturação, certamente não é apenas o fato de os idosos serem, cada vez mais, uma parcela economicamente representativa da população que motiva essa busca por uma nova imagem. O que também está em pauta é o papel do idoso na nossa sociedade. Nesse sentido, sob o signo de terceira idade, a velhice passou a ser alvo de políticas públicas e de gestões que buscam promover um envelhecimento bem sucedido, nas suas mais diversas acepções.

Nessa passagem da velhice da esfera familiar e pessoal para a esfera pública, compilam-se diferentes visões de velhice, muitas vezes contraditórias. Com o objetivo de tornálas mais homogêneas, Tornstam (1992 como citado em Debert, 2004) faz uma interlocução entre essas visões, separando-as em dois grandes grupos: de um lado, está a "perspectiva da miséria"; do outro, a visão do idoso como "fonte de recursos". Para a "perspectiva da miséria", o envelhecimento trazido pelos processos de modernização/ industrialização acaba relegando os idosos a uma vida sem significados, a um papel menor, tanto na família quanto na comunidade. Segundo o autor, essa perspectiva ganhou força a partir da década de 70, e buscava chamar atenção do poder público e da sociedade para a situação do idoso. Já a visão como fonte de recursos é mais atual, e o próprio Tornstam, na sua pesquisa sobre velhice na Suécia, defende a ideia de que o problema da velhice surge mais de uma superestimação dos jovens sobre esse tema do que, de fato, da realidade do idoso em si. Em outras palavras, as pesquisas realizadas com os idosos mostravam um posicionamento muito mais positivo do que nas teorias apontadas pelos pesquisadores (Debert, 2004).

Apesar de, à primeira vista, essas duas visões parecerem antagônicas, uma olhada minuciosa permite enxergar suas complementaridades. Se levarmos em conta que a Suécia - local onde Tornstam (1992 como citado em Debert, 2004) realizou suas pesquisas - tem um dos maiores IDHs (Índice de Desenvolvimento Humano) do mundo, a noção de fonte de recurso faz total sentido. Por outro lado, olhando para outro contexto - por exemplo, o de uma idosa, viúva, pobre, brasileira - a perspectiva da miséria também estaria correta. Mesmo em países de enorme desigualdade social como o Brasil, essas duas imagens coexistem. Mas um cuidado deve ser tomado. À medida que se considera o velho uma fonte de recursos e capaz de obter respostas criativas para novas formas de sociabilidade em relação às suas experiências - ou seja, a postura ideal do sujeito em sua autogestão do envelhecimento - um lado perverso pode instaurar-se: "o de considerar como seres problemáticos aqueles que necessitam de motivação, aqueles aposentados e idosos que não se empenham em desenvolver uma nova carreira ou novo conjunto de atividades 
de lazer ou, ainda, que não se envolveram em programas de manutenção corporal" (Tornstam 1992 como citado em Debert, 2004, p. 206).

A lógica do biopoder perpassa sutilmente por essa transformação da velhice em uma política, tendo em vista que são bastante divulgadas as últimas novidades técnico-científicas que irão garantir melhor qualidade de vida, naturalizando-as, bem como naturaliza os objetos-sujeitos a quem se dirigem. O que se pretende colocar é a emergência do novo velho como um cruzamento de todos os vetores já expostos - evolução técnico-científica, propagação midiática, novos processos sociais, transição epidemiológica -, que formam os discursos dos especialistas e dos próprios corposvelhos. Mas ao se desenvolver esses novos mecanismos de proteção, precisa-se levar em conta a heterogeneidade dessa entidade demográfica que, cada vez mais, cresce e se torna mais heterogênea (Barros \& Castro, 2002; Debert, 2004).

Nesse contexto, ligam-se a esse novo velho os signos de atividade, participação, autogestão e produção, como não poderia deixar de ser no biopoder. A lógica anterior era a de que, se o velho não é necessariamente um doente, então é aquele que não é mais capaz de produzir. Ou as duas coisas. O que a nova concepção pretende é buscar no velho a saúde e a manutenção de suas capacidades funcionais para que, assim, ele possa produzir, ser ativo e jovem.

Minayo (2000) traz algumas reflexões que são pertinentes ao se buscar esse novo padrão social para os idosos. A primeira delas é a quebra da centralidade do trabalho, permitindo ao idoso construir sua identidade em uma ótica de não trabalho, mas de utilidade e de sentido de vida. A segunda delas é o pluralismo de ideias, de comportamento e de atividades que, com efeito, quebra estereótipos ideológicos e comportamentais. A terceira é a valorização da subjetividade como um plano importante em todos os níveis de vida, da ciência e das políticas.

Outra reflexão importante para se avaliar a nova posição do idoso é a trazida por Maia, Londero \& Renz (2008) a partir das leituras de Deleuze (1992) e de Pelbart (2003). Atualmente, as novas tecnologias de poder não se fecham mais no intuito de trancar ou de excluir, mas de acelerar. O ideal atual é absolutizar a velocidade, fazendo com que a velhice se torne um obstáculo, já que representa uma desaceleração. Dessa forma, busca-se desfazer esse obstáculo incluindo o idoso nessa lógica de velocidade a partir dessa nova imagem supracitada, que busca uma atividade para os velhos.

Parece-nos fundamental "dar à velhice (sem substanciá-la) espaços de reivindicação de outro tempo, lugares onde um outro regime de temporalidade permita o encontro com a vida e a construção de novas formas de estar no mundo" (Maia, Londero, \& Renza, 2008, p. 5). Dessa forma, a desaceleração ocorrida na velhice não seria uma impotência ou uma disritmia, mas uma possibilidade de existência, uma opção de dizer não às políticas públicas, aos conselhos midiáticos e afins que os incitam a pedir, a participar, a inscrever-se em algo. Outrossim, não se objetiva pressionar os idosos a buscar essas atividades, que certamente podem fazer bem a eles, e os grupos de convivência provam isso, mas o que está em pauta é "avaliar a capacidade dos excluídos de construírem um território a partir da própria desterritorialização a que são submetidos" (Pelbart, 2003, p. 8). 


\section{Considerações finais}

A velhice está em pauta! Na mídia, nos estudos acadêmicos, nas políticas públicas. Os desafios, impasses e inquietações colocam-se à vista para tornar realizável o que até então se considerava irrealizável: a própria velhice. $\mathrm{Na}$ era do biopoder, os desvios da normalidade foram cada vez menos tolerados, sendo patologizados e medicalizados. Buscou-se atacar doenças atreladas à velhice, seguindo-se um combate ao próprio envelhecimento, calcado em uma reclusão que visava a afastar assepticamente do âmbito social qualquer corpo que se afastasse do padrão de normalidade. Atualmente, a reclusão passa a ter sua vertente inclusiva, que tem por função, segundo Foucault, "ligar os indivíduos aos aparelhos de produção, formação, reformação ou correção de produtores" (1996, p.114).

O que se impõe para o futuro é a construção de um novo modo de considerar essa parcela da população, para a qual se exige uma atividade e a inserção na lógica de velocidade. O que se mostrou aqui é que, nessa inserção, é preciso se ter cuidados, a fim de não se reforçar ideais de normalidade e de anormalidade, de disseminar novas normas sob a égide dos saberes especializados. É preciso ir além do normal ou do anormal, evitar que, na luta por um envelhecimento sadio, ocorra, mais uma vez, uma disciplinação da velhice em uma lógica instrumental - e a normatização que lhe é subjacente acabe se tornando, em princípio, uma negação da alteridade ou de uma norma vital, como pontua Canguilhem.

O que se objetivou aqui foi oferecer possibilidades de pluralidade. Trata-se de colocar, em meio às inquietações e desafios, uma multiplicidade de velhices que não considerem os velhos meros seres biológicos de vida nua, mas agentes ativos de suas próprias experiências, de seguir, portanto, uma lógica diferente daquela que marca a velhice desde a Idade Média e de tornar o novo velho livre de identidades fixas e estigmatizadoras. Uma velhice saudável não é uma ficção de poeta, e todos aqueles que são responsáveis por cuidar terão de levar em conta a possibilidade de reinvenção e de ressignificação desses sujeitos. 


\section{Robson Kleber de Souza Matos}

Pós-graduado em Gestão Estratégica em Saúde Pública. Psicólogo do Centro de Referência Especializado de Assistência Social (CREAS-Goiana-PE) e Psicólogo clínico, Recife - PE - Brasil.

E-mail: robsonkmatos@gmail.com

\section{Luciana Leila Fontes Vieira}

Doutora em Saúde Coletiva pela Universidade Estadual do Rio de Janeiro e Professora do Programa de Pósgraduação em Psicologia da Universidade Federal de Pernambuco, Recife - PE - Brasil.

E-mail: lufontesvieira@hotmail.com

Endereço para envio de correspondência:

Avenida 17 de agosto, 357, Casa Forte. CEP: 52060-590. Recife, PE.

Recebido 21/03/2012, 1a Reformulação 17/06/2013, Aprovado 29/08/2013. 


\section{Referências}

Agra do Ó, A. (2008, abr./jun.). Norbert Elias e uma narrativa acerca do envelhecimento e da morte. História, Ciências, Saúde, 15(2), 389-400. doi: http://dx.doi.org/10.1590/S010459702008000200009

Albuquerque, J. A. G. (1995). Michel Foucault e a teoria do poder. In Tempo Social; Rev. Sociol. 7(1-2), 105-110.

Barros, R., \& Castro, A. (2002). Terceira idade: o discurso dos "experts" e a produção do "novo velho". Estud. Interdiscip. Envelhec., 4, 113-124.

Beauvoir, S. de. (1990). A velhice. Rio de Janeiro: Nova Fronteira (Trabalho original publicado em 1970).

Birman, J. (1997). Estilo e modernidade em psicanálise. São Paulo: Ed. 34.

Birman, J. (2006). Arquivos do mal-estar e da resistência. Rio de Janeiro: Civilização Brasileira. Canguilhem, G. (2002). O normal e o patológico. Rio de Janeiro: Forense Universitária.

Castro, E. (2009). Vocabulário de Foucault: um percurso pelos seus temas, conceitos e autores. (pp. 120-122). São Paulo: Autêntica.

Coelho, M. T. A. D., \& Almeida Filho, N. (1999). Normalpatológico, saúde-doença: revisitando Canguilhem. PHYSIS: Rev. Saúde Coletiva, 9(1), 13-36.

Costa, J. F. (1992). A inocência e o vício: estudos sobre o homoerotismo. Rio de Janeiro: RelumeDumará.

Debert, G. (1988). A antropologia e o estudo dos grupos e das categorias de idade. In M. M. Lins de Barros. Velhice ou terceira idade? Estudos antropológicos sobre identidade, memória e política. Rio de Janeiro: Editora Fundação Getúlio Vargas.

Debert, G. (2004). A reinvenção da velhice: socialização e processos de reprivatização do envelhecimento. São Paulo: EdUSP/FAPESP.

Deleuze, G. (1992). Conversações: 1972-1990. Rio de Janeiro: Ed. 34.

Deleuze, G., \& Guatari, F. (1997). Mil platôs: capitalismo e esquizofrenia. Rio de Janeiro: Ed. 34.

Elias, N. (2001). A solidão dos moribundos, seguido de envelhecer e morrer. Rio de Janeiro: Jorge Zahar.

Ewald, F. (1993). Foucault, a norma e o direito. Lisboa: Veja.

Foucault, M. (1993). Microfísica do poder (11a. ed.). Rio de Janeiro: Graal.

Foucault, M. (1994). História da sexualidade 1: a vontade de saber. Lisboa: Relogio d'Água Editores Ltda.

Foucault, M. (1996). A verdade e as formas jurídicas. Rio de Janeiro: NAU.

Foucault, M. (1997). Vigiar e punir: nascimento da prisão (16a ed.). Petrópolis, RJ: Vozes.

Foucault, M. (1998). O nascimento da clínica. Rio de Janeiro: Ed. Forense.

Foucault, M. (1999). Em defesa da sociedade: Curso no Collége de France (1975-1976). São Paulo: Martins Fontes.

Foucault, M. (2008). Segurança, território, população: curso dado no Collège de France (1977-1978). São Paulo: Martins Fontes.

Goldfarb, D. C. (1998). Corpo, tempo e envelhecimento. São
Paulo: Casa do Psicólogo.

Groisman, D. (2002). A velhice, entre o normal e o patológico. História, Ciências, Saúde: Manguinhos 9(1), 61-78. doi: http:// dx.doi.org/10.1590/S0104-59702002000100004

Haber, C. (1986). "Geriatrics: a specialty in searchof specialists." Em David Van Tassel et al., Old Age in a bureaucocratic society. (pp. 66-84). Nova York: Greenwood Press.

Katz, S. (1996). Disciplining old age: The formation of gerontological knowledge. Charlottesville: University Press of Virginia.

Maia, G. F., Londero, S., \& Henz, A. O. (2008, jan./mar.) Velhice, instituição e subjetividade. Interface - Comunic., Saúde, Educ., 12(24), 49-59. doi: http://dx.doi.org/10.1590/S141432832008000100005

Minayo, M. C. (2000). "A vida e a saúde do idoso na sociedade global e pós-industrial". Arquivo de geriatria e gerontologia, $4(2), 169-181$.

Minois, G. (1999). História da velhice do ocidente: da antiguidade ao renascimento. Lisboa: Editorial Teorema, Ltda.

Peixoto, C. A. (1998). Entre o estigma e a compaixão e os termos classificatórios: velho, velhote, idoso, terceira idade... In M. M. Lins de Barros (Org.), Velhice ou terceira idade? Estudos antropológicos sobre identidade, memória e política (pp. 6984). Rio de Janeiro: Fundação Getúlio Vargas.

Pelbart, P. P. (2003). O corpo do informe. In P. P. Pelbart. Vida capital (pp. 42-51) São Paulo: Iluminuras.

Pitanga, D. A. (2006). Velhice na cultura contemporânea. Dissertação de mestrado em Psicologia Clínica. Centro de Teologia e Ciências Humanas, Universidade Católica de Pernambuco, Recife, PE.

Pogrebinschi, T. (2004). Foucault, para além do poder disciplinar e do biopoder. Lua Nova, 63, 180-201. http://dx.doi. org/10.1590/S0102-64452004000300008

Revista Galileu. (2011, fev.). São Paulo: Globo, no 235

Silva, M. R. A., Leal, M. C. C., Marques, A. P. O., Salomão, D. A. Rapozo, J., Matos, R. K. S., Santos, L. B. M., Cunha, L. J. R., \& Savanne, T. (2010). Intergeracionalidade e sexualidade: espaço de troca de saberes entre idosos e discentes de graduação. In 8 Encontro Nacional Universitário de Diversidade Sexual. Campinas, SP. Recuperado em 29 maio, 2013, de www. identidade.org.br/2010/GATS_POVO/Mario\%20Roberto.doc

Silva, L. R. F. (2008). Da velhice à terceira idade: o percurso histórico das identidades atreladas ao processo de envelhecimento. Hist. Ciênc. Saúde-Manguinhos, 15(1), 155-168. Doi: http://dx.doi. org/10.1590/S0104-59702008000100009

Soares, S. S. (2005). O processo de envelhecimento e as mudanças edifício-identidárias. Recuperado em 10 julho, 2011, de http://www.estadosgerais.org/atividades_atuais/ processo_de_envelhecimento.shtml

Swift, J. (1739). Verses ontheDeathofDoctorSwift. Recuperado em 10 outubro, 2010, de http://www.english.gsu.edu/ mbrown/ Texts/Swift_works/versedeathswift.pdf

Veiga-Neto, A., \& Lopes, M. C. (2007). Inclusão e governamentalidade. Educação e Sociedade, 28(100), 947-963. doi: http://dx.doi.org/10.1590/S0101-73302007000300015

Wanjaman, S., Oliveira, A. M., \& Oliveira, E. L. (2004). Os idosos no mercado de trabalho: tendências e consequências. In A. A Camarano (Org.), Os novos idosos brasileiros: muito além dos anos 60? (pp. 453-479). Rio de Janeiro: IPEA. 